\title{
C3 glomerulopathy disease
}

\section{C3 glomerulopati hastalığı}

\author{
Can Huzmeli ${ }^{1}$, Mehmet Hadi Akkus ${ }^{2}$, Ferhan Candan ${ }^{3}$
}

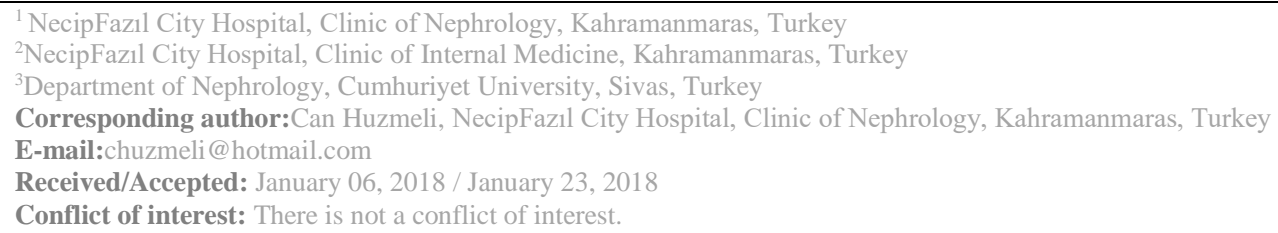

\section{SUMMARY}

C3 glomerulopathy is a recently defined disease that encompasses a group of kidney diseases caused by abnormal control of complement activation. $\mathrm{C} 3 \mathrm{G}$ is characterized bydeposition of dominant complement $\mathrm{C} 3$ with absence/traces of immunoglobulins in the glomeruli. C3G may be classified into dense deposit disease (DDD) and C3 glomerulonephritis $(\mathrm{C} 3 \mathrm{GN})$. DDD and $\mathrm{C} 3 \mathrm{GN}$ are rare forms of glomerulonephritis that affect both children and adults. In treatment $\mathrm{C} 3 \mathrm{G}$ include on specific treatment, plasma therapy, immunsupressive and complement inhibition. Keywords: C3 glomerulopathy, C3 glomerulonephritis, dense deposit disease, complementdisorder

\section{ÖZET}

C3 glomerulopati (C3G), kompleman aktivasyonunun anormal kontrolü ile olușan bir grup böbrek hastalığını kapsayan yakın zamanda tanımlanmış bir hastalıktır. C3G glomerullerde immunoglobulin birikiminin trace ve yokluğu ile dominant olarak kompleman C3 birikimi ile karakterizedir. C3G C3 glomerulonefrit (C3GN) ve Dens Deposit Hastalığ1 (DDD) diye iki grup hastalıktan oluşmaktadır. DDD ve C3GN nadir görülmektedir ve her iki hastalık hem çocuklarda hemde erişkinlerde görülmektedir. $\mathrm{C} 3 \mathrm{G}$ spesifik tedavisinde, plazmaferez, immünsüpresif tedavi ve kompleman inhibitörlerini içermektedir.

Anahtar sözcükler: C3 glomerulopati, C3 glomerulonefrit, dens deposit hastaliği, kompleman bozukluklar1

\section{INTRODUCTION}

$\mathrm{C} 3$ glomerulopathy $(\mathrm{C} 3 \mathrm{G})$ is a rare renal disease associated with the complement. The frequency of occurrence is two per million people ${ }^{1}$. Both genders are equal. Although it can be seen at any age, it is more common in childhood and young adults. $\mathrm{C} 3 \mathrm{G}$ is divided into two in itself as C3 glomerulonephritis (C3GN) and Dens Deposit Disease (DDD $)^{2}$. DDD has an estimated prevalence of 2 to 3 per million populations ${ }^{3}$. In a study conducted, 5-year renal biopsy results were evaluated and $\mathrm{C} 3 \mathrm{G}$ was detected in $0.7 \%$ of them. In this study, DDD and C3GN were found at an equal rate. When DDD patients were compared with $\mathrm{C} 3 \mathrm{GN}$ patients they were found to be younger. Also in study, C3G was found more frequently in men ${ }^{4}$. Differential diagnosis between DDD and C3 GN is necessary. Also, glomerular disease caused by mechanisms other than alternative complement dysregulation may occasionally satisfy " $\mathrm{C} 3$-dominant deposition with scanty immunoglobulins" as stated in the current consensus report ${ }^{5}$ Pathogenesis-based classification in glomerular disease is an important prospect for appropriate therapies, but the entity of C3 GN still presents dilemmas in diagnostic and pathogenetic basis. The aim of this review was to understand of the specific pathophysiology of this disease and ordering logical therapies. 


\section{PATHOGENESIS AND CLINICAL FEATURES}

C3G immunofluorescence (IF) or immunohistochemical (IHC) methods are characterized with $\mathrm{C} 3$ dominant accumulation in glomerular and $\mathrm{C} 3$ dominant accumulation in glomerular and no or minimal immunoglobulin accumulations. The most common patterns in light microscopy (IM) in C3G may include membranoproliferative glomerulonephritis (MPGN), diffuse proliferative glomerulonephritis, mesangial proliferative glomerulonephritis and even necrotizing and crescentic glomerulonephritis. Rarely, glomerular can be normal with $\mathrm{IM}^{5}$. Subendothelial intramembranous associated with wear of lamina densa and glomerular basement membrane thickening together with various combinations of subepithelial deposits and mesangial cell proliferation increase can be observed. At the same time, C3GN may show large subepithelial hump like deposits defined for DDD. In light microscopy, DDD is mostly found in mesengial proliferation. Significant endocapillary proliferation, leukocyte infiltration and crescent can be seen. In both diseases, predominant C3 stained with IHC, so EM is required for discrimination of both diseases. In $\mathrm{C} 3 \mathrm{GN}$, discrete C3 deposits are located in the mesangium and along the capillary wall, whereas in DDD C3 deposits are more intense and located in the mesangium and within the glomerular basement membranes ${ }^{5-7}$.

In MPGN IF staining, if there is positive immunoglobulin $\pm \mathrm{C} 3$ staining, it is divided into as glomerulonephritis associated with immunoglobulin (monoclonal gammopathy, autoimmune diseases, infectious diseases), if there is negative immunoglobulin and positive C3 staining, it is divided into as complement associated glomerulonephritis (DDD and C3GN). Besides $\mathrm{C} 3 \mathrm{G}$, there are different diseases showing dominant $\mathrm{C} 3$ accumulation with IF staining. Among these, post infectious glomerulonephritis (PIGN), infectious diseases (such as infective endocarditis), autoimmune diseases and paraproteinemia related diseases ${ }^{8-10}$.

In cases of PIGN, there may be isolated staining for $\mathrm{C} 3$ on IHC/IF. Therefore, the distinction between PIGN and C3GN is required. PIGN is an immune complex-mediated glomerular injury. In a study conducted, an abnormality (acquired autoantibodies and genetic mutations) was found in the AP complement pathway in 11 PIGN patients. This is called atypical PIGN. However, when evaluating the data, most of these patients are classified as $\mathrm{C} \mathrm{GN}^{8}$. In PIGN patients, there is a rapid recovery at renal function, haematuria, proteinuria and the level of the complement. In patients followed as PIGN, 8 weeks long hypocomplementemia, $>500 \mathrm{mg}$ proteinuria contin one year later after diagnosis and/or if there is a progressive decrease in renal function, alternate complement path must be investigated and can be renamed as $\mathrm{C} 3 \mathrm{G}^{11}$. $\mathrm{C} 3 \mathrm{G}$ is distinct from atypical hemolytic uremic syndrome (aHUS) although both diseases are due to abnormal control of the alternative pathway. (e.g.; abnormalities in $\mathrm{CFH}$ result in uncontrolled activation of $\mathrm{C} 3$ through the $\mathrm{AP}$ and associate with susceptibility to both $\mathrm{C} 3 \mathrm{G}$ and aHUS $)^{5}$. C3G and aHUS are rarely seen together. In aHUS, complement activation occurs on the glomerular or microvascular endothelium. Electron dense deposit on EM is not seen in most cases. Also glomerular $\mathrm{C} 3$ is not detected on IHC / IF. The minimum set of genes $(C F H, C D 46$, CFI, C3, CFB, THBD, CFHRI, CFHR5, and $D G K E$ ) should be screened. In a patient with aHUS, the identification of a pathogenic genetic variant strengthens the diagnosis and initiates with accuracy the cause of the disease, facilitating patient management, effective treatment, and genetic counseling. But despite that in $\mathrm{C} 3 \mathrm{G}$, existing knowledge is inadequate except in cases of CFHR rearrangements leading to fusion genes (such as CFHR5 nephropathy), FH or FI deficiency, or with $\mathrm{C} 3$ mutations ${ }^{12}$. Initial clinical manifestations of DDD and C3GN may be preceded by upper respiratory tract infection. Streptococcal infection C3G among infections is the most common triggering factor. Clinically, renal involvement of both patients is similar and nonspecific. Haematuria, hypertension, proteinuria, nephritic syndrome, nephrotic syndrome and renal insufficiency are defined. It may be accompanied by partial lipodystrophy in DDD patients. Retinal complications (such as drusen and atrophy) are commonly in C3G patients ${ }^{13}$. Eye findings have previously been defined for DDD. Retinal drusen or whitishyellow subepithelial deposits evident on fundoscopy have also been described in patients with DDD or C3GN. Drusen affect vision, initially only mildly but severely in the longer term ${ }^{13-14}$.

C3G alternative complement pathway should be assessed. Serological complement assays may be informative in these patients. Serum membrane attack complex, complement $\mathrm{C} 3$ and $\mathrm{C} 4$ level should be observed. Besides, observing of $\mathrm{CFH}$, paraprotein and $\mathrm{C} 3 \mathrm{NeF}$ is recommended. Specific 
activation of alternative complement pathway may characterize with low $\mathrm{C} 3$, low factor $\mathrm{B}$ and normal C4 level, increased degradation C3 products, low $\mathrm{C} 5$ and increased solubility C5b-9 and $\mathrm{C} 5 \mathrm{a}$ levels. But these anomalies can change during the course of the disease. CFB deficiency may be associated with activation of uncontrolled alternative complement pathway. In the absence of $\mathrm{CFH}$ it is associated with $\mathrm{C} 3 \mathrm{G}$. Low level of complicated C3 supports C3G. Complement C4 is usually at the normal value. Acquired antibodies should be observed ( $\mathrm{C} 3 \mathrm{NeF}, \mathrm{CFH}$ autoantibody, CFB autoantibody) and genetic mutations can be made (C3, CFH, CFI. CFB, MCP and CFHR $)^{5,10}$.

Complement is part of the innate immune system and is composed of over 30 proteins. The complement system can be activated in 3 different ways. These are known as the classical pathway, the mannose-binding lectin pathway and the alternative complement pathway. The alternative complement pathway is different from others because of spontaneous active ${ }^{15}$. Overactivation of the alternative complement pathway by autoantibodies or mutations or as a result of regulatory defect $\mathrm{C} 3 \mathrm{G}$ can develop. Complement C3 deposition in the renal and systemic C3 consumption are hallmark feature of $\mathrm{C} 3 \mathrm{G}$. $\mathrm{C} 3 \mathrm{NeF}$, anti-complement factor $\mathrm{H}$, anticomplement fctor I, anti-complement factor B, anti-C3b were determined among autoantibodies. CFH, CFB, CFI, MCP, complement C3, CFHR 5, CFHR3-1 were determined among complement mutations ${ }^{16-18}$. In a study of 134 patients with DDD, C3GN and MPGN type I diseases, alternative complement pathway hereditary or acquired complicated impairment was detected in $\% 71 . \mathrm{C} 3 \mathrm{NeF}$ is the first defined autoantibody. The $\mathrm{C} 3$ connects and stabilizes the converter. In this study, $86.4 \%$ of $\mathrm{C} 3 \mathrm{NeF}$ DDD patients and $45,3 \%$ of $\mathrm{C} 3 \mathrm{GN}$ patients were detected ${ }^{19}$.

Familial $\mathrm{C} 3 \mathrm{G}$ are five complement factor $\mathrm{H}$ related genes: CFHR1, CFHR2, CFHR3, CFHR4, and CFHR5. CFHR5 nephropathy is C3GN subtype. In Cyprus, CFHR5 nephropathy is a hereditary renal disease. It usually develops after upper respiratory tract. Clinically, persistent microscopic haematuria, synpharyngitic macroscopic hematuria and renal dysfunction characterize CFHR5 nephropathy. There is CFHR5 mutation. CFHR5 nephropathy is autosomal dominant. With progression to end stage renal failure (ESRD) is common lately, renal transplant is successful in these patients ${ }^{5,20-21}$. The CFHR3-1 gene is cause of atypical hemolytic uremic syndrome and C3G. The CFHR3-1 gene is also common in healthy populations ${ }^{22}$.
In studies evaluating the prognosis of $\mathrm{C} 3 \mathrm{G} ; 10$ year renal survival was lower than $50 \%$ and after 28 months of follow-up, the rate of ESRD development rate was found as $29 \%$ (a total of 21 DDD patients and $59 \mathrm{C} 3 \mathrm{GN}$ patients were included in this study) ${ }^{23}$. In another study, 10year renal survival (a total of 29 DDD patients, 49 type I MPGN patients and $56 \mathrm{C} 3 \mathrm{GN}$ patient were included in this study) was $63,5 \%$ of the patients after diagnosis ESRD develops. Also in this study, the prognosis of DDD patients is reported to be worse than the other two diseases ${ }^{19}$. Being patients older than 16 years old, having DDD, crescentic glomerulonephritis, renal dysfunction, having IM MPGN pattern detection is considered as a high risk for progression of ESRD ${ }^{19,23}$.

\section{TREATMENT}

C3G treatment is in the form of nonspecific treatment, immunosuppressive treatments, plasma treatment, inhibition of complement activation and renal transplantation. Nonspecific treatment, blood pressure control, reduction of proteinuria and reduction of serum lipid level has beneficial effects on the progression of $\mathrm{C} 3 \mathrm{G}$. Angiotensin receptor blockers and angiotensin converting enzyme inhibitors are used in proteinuric renal diseases as antihypertensive and antiproteinuric. Their use has been associated with better survival in patients with MPGN. Antiproteinuric antihypertensives are recommended in patients with $\mathrm{C} 3 \mathrm{G}^{19,24}$. According to expert opinion of Kidney Disease Improving Global Outcomes" (KDIGO); optimal blood pressure control (Priority agents include angiotensin converting enzyme inhibitors and angiotensin receptor blockers) and lipid control are recommended in all patients ${ }^{12}$.

Due to lack of immunosuppressive therapy controlled studies in treatment of $\mathrm{C} 3 \mathrm{G}$, severe inflammation findings, progressive glomerular filtration loss in renal biopsy and/or its use in patients with proteinuria is limited. McCaughan reported a failure to respond to glucocorticoid, mycophenolate mofetil and rituximab therapy ${ }^{25}$. Bomback et al. showed treatment failure of the use of prednisolone and mycophenolate mofetil in a C3GN ${ }^{26}$. On the contrary, clinical improvement in many in acute glomerulonephritis cases containing cresent with steroid therapy has been reported during $\mathrm{C} 3 \mathrm{G}$ pediatric series ${ }^{27}$. Moderate disease (over $500 \mathrm{mg} / 24 \mathrm{~h}$ of urine protein or moderate inflammation on renal biopsy or a risk of progressive disease) according to KDIGO; prednisolone and mycophenolate mofetil are recommended for treatment. Severe disease (over 
$2000 \mathrm{mg} / 24 \mathrm{~h}$ of urine protein or Severe inflammation represented by marked endo- or extracapillary proliferation with or without crescent formation on renal biopsy or a risk of progressive disease despite immunosuppression and supportive therapy) according to KDIGO; In patients with rapid progressive renal disease, methylprednisolone pulse dosing or other anticellular immunesuppressants have had limited success and data are insufficient to recommend eculizumab as a first-line agent ${ }^{12}$. DDD-associated anti-Cfb / C3b autoantibody was reported that in a case treated successfully with rituximab ${ }^{28}$. In a study by Robosco et al they have shown that immunosuppressive therapy was particularly effective in the treatment of C3GN with mycophenolate mofetil therapy as an immunosuppressive adjunct ${ }^{29}$. In addition, immunosuppressive treatment may possibly be predominantly effective in relation to autoantibody from C3GN forms. In patients with proven antibodies against complement regulatory protein, drugs like steroids, cytotoxic drugs and rituximab may be useful. In patients with crescentic GN, these drugs together with steroids may also have a role ${ }^{19,29-30}$.

Although plasma exchange should theoretically be useful as it can remove autoantibodies and mutated proteins, it has met with only limited success. Licht et al, reported efficacy of plasma therapy in a sibling pair with DDD and a factor $\mathrm{H}$ deficiency secondary to a mutation in $\mathrm{CFH}{ }^{31}$. Both Banks and Krmar et al have reported that patients with acute renal failure and DDD were treated with plasma exchange, cyclophosphamide and methylprednisolone ${ }^{32-33}$. McCaughan et al, on the other hand, did not respond to treatment plasmapheresis, steroids and rituximab in patients with recurrent DDD after renal transplant. This patient has been shown to recover after treatment with eculizumab ${ }^{25}$. Kurtz et al. have shown that long-term plasmapheresis is effective and safe in a recurrent DDD patient. The level of $\mathrm{C} 3 \mathrm{NeF}$ is reduced and serum creatinin are kept constant with plasmapheresis ${ }^{34}$. In $4 \mathrm{C} 3 \mathrm{GN}$ patients with $\mathrm{C} 3 \mathrm{NeF}$ detected (excluding all other known complement factor mutations) plasma therapy, corticosteroids and mycophenolate mofetil was found effective with regimen therapy ${ }^{35}$. In a study of hemolytic uremic syndrome patients, MCP mutation patients were found to have better prognosis than patients without mutation and $\mathrm{CFH}$, effect of plasma treatment on MCP mutations could not be shown (both plasma treatment and no plasma treatment improved the majority of patients). It was emphasized that the renal transplant outcomes were successful in these patients. When plasmapheresis or plasma exchange is given alone or with other medications, $85 \%$ in non-mutated, $94 \%$ in those with $\mathrm{CFH}$ mutations, $71 \% \mathrm{MCP}$ mutation and $61 \%$ CFI mutation were found. CFH, CFI, C3 and $\mathrm{CFB}$ are produced by the liver. Concomitant liver transplantation together with kidney transplantation can be used effectively for them ${ }^{36-}$ ${ }^{37}$. Consequently, plasma therapy may be useful in patients with regulatory factor deficiency or with circulating $\mathrm{C} 3 \mathrm{NeF}$. Plasma infusion may replace the deficient factor. The frequency and duration of plasma therapy is unclear.

Cleavage of $\mathrm{C} 5$ is blocked by Eculizumab, consequently it blocks both formation of C5b-9 and the production of the anaphylatoxin C5a. Eculizumab is used in the treatment of Paroxysmal nocturnal hemoglobinuria and aHUS. For both diseases, eculizumab in adult is initially administered 600-900 mg intravenously weekly. Maintenance of treatment is administered 900 $1200 \mathrm{mg} / 2$ weeks. The main adverse effects are infusion reactions and infections, especially meningococcal infections. Before induction of eculizumab Meningococcal vaccination is required and until 2 weeks after vaccination prophylactic treatment with appropriate antibiotics should be preserved. There are case reports and small clinical trials that have demonstrated the efficacy of intravenous treatment with eculizumab. In the study C3G (3 DDD and 3 C3GN) of Bomback et al it found to be effective in the inhibition of terminal complex cascade of treatment with eculizumab. Besides, serum membrane attack complex height in patients may predict response to treatment with eculizumab. At the end of this study, it was emphasized that treatment with eculizumab might be suitable for C3G patients ${ }^{38}$. Oosterveld et al showed that eculizumab treatment was successful in paediatric DDD $(\mathrm{C} 3 \mathrm{NeF}$ in 3 patients, anti-CFH in one patient, CFHR1-CFHR3 mutation in one) patients. Also, two patients were discontinued dialysis treatment. All of the patients had well tolerated the treatment with eculizumab ${ }^{39}$. In a DDD case showing nephrotic proteinuria, low $\mathrm{C} 3$, lack of $\mathrm{CFH}, \mathrm{CFH}$ polymorphism and $\mathrm{C} 3 \mathrm{NeF}$ antibody positivity, it has been found that eculizumab treatment is effective ${ }^{40}$. In a case having C3GN diagnosis (CFHR1-CFHR3 mutation) Inman et al has presented a case of dialysis treatment discontinued 5 months after treatment with eculizumab ${ }^{41}$. C3GN has been treated successfully in a few cases with eculizumab treatment ${ }^{42-43}$. 
Soluble Complement receptor 1 (sCR1) is complement C3 inhibitor (sCR1 is inhibits the complement activation cascades by binding both $\mathrm{C} 3 \mathrm{~b}$ and $\mathrm{C} 4 \mathrm{~b}$ ). sCR1 prevented $\mathrm{C} 3$ convertase activity in normal and pathologic conditions. sCR1 also prevents dysregulation of the alternative pathway $\mathrm{C} 3$ convertase in the presence of $\mathrm{C} 3 \mathrm{NeF}$ and genetic mutations. As in vivo, $\mathrm{C} 3 \mathrm{G}$ stopped the dysregulation of alternative complement pathway sCR1 in two mice and normalized plasma $\mathrm{C} 3$ levels. These changes were accompanied by reduced deposition of new $\mathrm{iC} 3 \mathrm{~b}$ and clearance of old iC $3 \mathrm{~b}$ in the glomerular basal membrane ${ }^{44-45}$.

Cp40 complement is $\mathrm{C} 3$ inhibitor. $\mathrm{Cp} 40$ prevents formation of $\mathrm{C} 5$ convertase, production of $\mathrm{C} 5 \mathrm{a}$, soluble C5b-9 and lytic membrane attact complex. Cp40 extinguishes impaired complete disregulation by genetic mutations and autoantibodies such as $\mathrm{C} 3 \mathrm{NeF}$ and $\mathrm{C} 4 \mathrm{NeF}$ and prevents the lysis of complement-associated erythrocytes. It is seen as a specific treatment for the disease in $\mathrm{C}_{3} \mathrm{G}^{46}$.

It has turned out that steroid therapy, eculizumab therapy, renal transplantation and liver transplant and $\mathrm{CFH}$ replacement are ineffective for drusen treatment. Laser therapy stabilizes vision in some cases of neovascularization. Also, recurrent bevacizumab and anti-VEGF injections may correct the sight in DDD patients ${ }^{38,47-50}$.

Because $\mathrm{C} 3 \mathrm{G}$ patients are usually children and young adults, the renal transplantation rate is high in these patients. Besides, renal transplantation provides good survival in patients with ESRD. However, Recurrent of disease in patients with C3G and graft loss rates are high. In carried out studies, transplantation recurrence rates as high as $66.7 \%$ of patients with $\mathrm{C} 3 \mathrm{GN}$ and up to $70 \%$ of patients with $\mathrm{DDD}^{51-52}$

\section{CONCLUSION}

Consequently, more detailed laboratory and clinical data about the disease will be obtained after the new classification of C3G. In addition, more specific treatment modalities will emerge. Also, differential diagnosis of these diseases should be made from other with alternative complement pathway disorders. In the treatment of $\mathrm{C} 3 \mathrm{G}$, angiotensin receptor blockers and angiotensin converting enzyme inhibitors are recommended. $\mathrm{C} 3 \mathrm{G}$ are conflicting results regarding treatment. More extensive and comprehensive research is needed for targeted treatments.

\section{REFERENCES}

1. Medjeral-Thomas NR, O'Shaughnessy MM, O'Regan JA, Traynor C, Flanagan M, Wong L, Teoh CW, Awan A, Waldron M, Cairns T, O'Kelly P, Dorman AM, Pickering MC, Conlon PJ, Cook HT. C3 glomerulopathy: clinicopathologic features and predictors of outcome. Clin $\mathbf{J}$ Am Soc Nephrol 2014; 9: 46-53.

2. Sethi S, Fervenza FC, Zhang Y, Zand L, Vrana JA, Nasr SH, Theis JD, Dogan A, Smith RJ. C3 glomerulonephritis: clinicopathological findings, complement abnormalities, glomerular proteomic profile, treatment, and follow-up. Kidney Int 2012; 82: 465-73.

3. Barbour TD, Pickering MC, Terence Cook $\mathrm{H}$. Dense deposit disease and C3 glomerulopathy. Semin Nephrol 2013; 33: 493-507.

4. Viswanathan GK, Nada R, Kumar A, Ramachandran R, Rayat CS, Jha V, Sakhuja V, Joshi K. Clinico-pathologic spectrum of C3 glomerulopathy-an Indian experience. Diagn Pathol 2015; 10:6.

5. Pickering $M C$, D'agati VD, Nester CM, Smith RJ, Haas M, Appel GB, Doyle M et al. C3 glomerulopathy: consensus report. Kidney Int 2013; 84: 1079-89.

6. Walker PD. Dense doposit disease: New in sights. Curr Opin Nephrol Hypertens 2007; 16: 204-12.

7. Riedl $\mathrm{M}$, Thorner $\mathrm{P}$, Licht C. C3 Glomerulopathy. Pediatr Nephrol 2017; 32: 43-57.

8. Sethi S, Fervenza FC, Zhang Y, Zand L, Meyer NC, Borsa N, Smith RJ. Atypical postinfectious glomerulonephritis is associated with abnormalities in the alternative pathway of complement. Kidney Int 2013; 83: 293-99.

9. Bridoux F, Desport E, Frémeaux-Bacchi V, Chong VF, Gombert JM, Lacombe C, Quellard N, Touchard G. Glomerulonephritiswith isolated C3 deposit $s$ and monoclonal gammopathy: a for tuitous association? Clin J Am Soc Nephrol 2011; 6: 2165-74.

10. Salvadori M, Rosso G. Reclassification of membranoproliferative glomerulonephritis: Identification of a new GN: C3GN. World J Nephrol 2016; 5: 308-20. 
11. Khalighi MA, WangS, Henriksen KJ, Bock M, Keswani M, Meehan SM, Chang A. Revisiting post-infectious glomerulonephritis in the emergingera of C3 glomerulopathy. Clin Kidney J 2016; 9: 397-402.

12. Goodship THJ, Cook HT, Fakhouri F, Fer Fervenza FC Frémeaux-Bacchi V, Kavanagh D, Carla M. Nester CM, Noris M, Pickering MC, Rodríguez de Córdoba S.Roumenina LT, Sethi S, Smith RJH. Atypical hemolytic uremic syndrome and C3 glomerulopathy: conclusions from a "Kidney Disease: Improving Global Outcomes" (KDIGO) Controversies Conference. Kidney Int 2017; 91: 539-51.

13. Savige J, Amos L, Ierino F, Mack HG, Symons RC, Hughes P, Nicholls $\mathrm{K}$, Colville D. Retinal disease in the C3 glomerulopathies and the risk of impaired vision. Ophthalmic Genet 2016; 37: 36976.

14. Cameron JS, Turner DR, Heaton J, Williams DG, Ogg CS, Chantler C, Hicks J. Idiopathic mesangiocapillary glomerulonephritis: Comparison of types I and II in children and adults and long-term prognosis. Am J Med. 1983; 74: 175-92.

15. Noris M, Remuzzi G. Overview of complement activation and regulation. Semin Nephrol 2013; 33: 479-92.

16. Zhang $\mathrm{Y}$, Meyer NC, Wang K, Nishimura C, Frees K, Jones M, Katz LM, Sethi S, Smith RJ. Causes of alternative pathway dysregulation in dense deposit disease. Clin J Am SocNephrol 2012; 7: 265-74.

17. Goodship TH, Pappworth IY, Toth T, Denton M, Houlberg K, McCormick F, Warland D, Moore I, Hunze EM, Staniforth SJ, Hayes C, Cavalcante DP, Kavanagh D, Strain L, Herbert AP, Schmidt CQ, Barlow PN, Harris CL, Marchbank KJ. Factor H autoantibodies in membranoproliferative glomerulonephritis. Mol Immunol 2012; 52: 200-6.

18. Strobel S, Zimmering M, Papp K, Prechl J, Józsi M. Anti-factor B autoantibody in dense deposit disease. Mol Immunol 2010; 47: 1476-83.

19. Servais A, Noël LH, Roumenina LT, Le Quintrec M, Ngo S, Dragon-Durey MA, Macher MA, Zuber J, Karras
A, ProvotF, Moulin
B, Grünfeld

JP, Niaudet P, Lesavre P, Frémeaux-Bacchi $V$.Acquired and genetic complement abnor malities play a critical role in dense deposit disease and other C3 glomerulopathies. Kidney Int 2012; 82: 454-64.

20. Gale DP, de Jorge EG, Cook HT, MartinezBarricarte R, Hadjisavvas A, McLean AG, Pusey CD, Pierides A, Kyriacou $\mathrm{K}$, Athanasiou Y, Voskarides K, Deltas C, Palmer A, Frémeaux-Bacchi V, de Cordoba SR, Maxwell PH, Pickering MC. Identification of a mutation in complement factor $\mathrm{H}$-related protein 5 in patients of Cypriotorigin with glomerulonephritis. Lancet 2010; 376 (9743): 794-801.

21. Athanasiou $\mathrm{Y}$, Voskarides $\mathrm{K}$, Gale DP, Damianou L, Patsias C, Zavros M, Maxwell PH, Cook HT, Demosthenous $\mathrm{P}$, Hadjisavvas A, Kyriacou $\mathrm{K}$, Zouvani I, Pierides A, Deltas C. Familial C3 glomerulopathy associated with CFHR5 mutations: clinical characteristics of 91 patients in 16 pedigrees. Clin J Am Soc Nephrol 2011; 6: 1436-46.

22. Fakhouri F, Frémeaux-Bacchi V, Noël LH, Cook HT, Pickering MC. C3 glomerulopathy: A new classification. Nat Rev Nephrol 2010; 6: 494-9.

23. Medjeral-Thomas NR, O'Shaughnessy MM, O'Regan JA, Traynor C, Flanagan M, Wong L, Teoh CW, Awan A, Waldron M, Cairns T, O'Kelly P, Dorman AM, Pickering MC, Conlon PJ, Cook HT.C3 glomerulopathy: clinicopathologic features and predictors of outcome. Clin J Am Soc Nephrol 2014; 9: 46-53.

24. Kidney Disease: Improving Global Outcomes (KDIGO) Glomerulonephritis Work Group. KDIGO Clinical Practice Guidline for Glomerulonephritis. General principles in the management of glomerular disease. Kidney Inter Suppl. 2012; 2: 15662.

25. McCaughan JA, O'Rourke DM, Courtney AE. Recurrent dense deposit disease after renal transplantation: an emerging role for complementary therapies. Am J Transplant 2012; 12: 1046-51.

26. Bomback AS, Appel GB. Pathogenesis of the C3 glomerulopathies and reclassification of MPGN. Nat Rev Nephrol 2012; 8: 634-42. 
27. West CD, McAdams AJ, Witte DP. Acutenon-proliferative glomerulitis: a cause of renal failure unique to children. Pediatr Nephrol 2000; 14: 786-93.

28. Chen Q, Müller D, Rudolph B, Hartmann A, Kuwertz-Bröking E, Wu K, Kirschfink M, Skerka C, Zipfel PF. Combined c3b and factor B autoantibodies and MPGN type II. N Engl J Med 2011; 365: 2340-2.

29. Rabasco C, Cavero T, Román E, RojasRivera J, Olea T, Espinosa M, Cabello V, Fernández-Juarez G, González F, Ávila A, Baltar JM, Díaz M, Alegre R, Elías $\mathrm{S}$, Antón M, Frutos MA, Pobes A, Blasco M, Martín F, Bernis C, Macías M, Barroso S, de Lorenzo A, Ariceta G, LópezMendoza M, Rivas B, López-Revuelta K, Campistol JM, Mendizábal S, de Córdoba SR, Praga M. Spanish Group for the Study of Glomerular Diseases (GLOSEN). Effectiveness of mycophenolate mofetil in C3 glomerulonephritis. Kidney Int 2015; 88: 1153-60.

30. De Vriese AS, Sethi S, Van Praet J, Nath KA, Fervenza FC. Kidney disease caused by dysregulation of the complement alternative pathway an etiology approach. J Am Soc Nephrol 2015; 26: 2917-29.

31. Licht C, Weyersberg A, Heinen S, Stapenhorst L, Devenge J, Beck B, Waldherr R, Kirschfink M, Zipfel PF, Hoppe B. Successful plasma therapy for atypical hemolytic uremic syndrome caused by factor $\mathrm{H}$ deficiency owing to a novel mutation in the complement cofactor protein domain 15. Am J KidneyDis 2005; 45: 415-21.

32. Banks RA, May S, Wallington $T$. Acute renal failure in dense deposit disease: recovery after plasmapheresis. BrMed $\mathrm{J}$ (Clin Res Ed) 1982; 284: 1874-5.

33. Krmar RT, Holtbäck U, Linné T, Berg UB, Celsi G, Söderberg MP, Wernerson A, Szakos A, Larsson S, Skattum L, Bárány $P$. Acute renal failure in dense deposit disease: complete recovery after combination therapy with immunosuppressant and plasma exchange. ClinNephrol 2011; 75 Suppl 1: 4-10.

34. Kurtz KA, Schlueter AJ. Management of membranoproliferative glomerulonephritis type II with plasmapheresis. J ClinApher 2002; 17: 135-7.

35. Häffner $\mathrm{K}$, Michelfelder $\mathrm{S}$, Pohl $\mathrm{M}$. Successful therapy of C3Nef-positive C3 glomerulopathy with plasma therapy and immunosuppression. Pediatr Nephrol 2015; 30: 1951-9.

36. Caprioli J, Noris M, Brioschi S, Pianetti G, Castelletti F, Bettinaglio P, Mele C, Bresin E, Cassis L, Gamba S, Porrati F, Bucchioni S, Monteferrante G, Fang CJ, Liszewski MK, Kavanagh D, Atkinson JP, Remuzzi G; Genetics of HUS: the impact of MCP, CFH, and IF mutations on clinical presentation, response to treatment, and outcome. Blood 2006; 1081: 267-79.

37. Tran $\mathrm{H}$, Chaudhuri

A, Concepcion $\mathrm{W}$, Grimm PC. Use of eculizumab and plasma exchange in successful combined liver-kidney transplantation in a case of atypical HUS associated with complement factor $\mathrm{H}$ mutation. Pediatr Nephrol 2014; 29: 477-80.

38. Bomback AS, Smith RJ, Barile GR, Zhang Y, Heher EC, Herlitz L, Stokes MB, Markowitz GS, D'Agati VD, Canetta PA, Radhakrishnan J, Appel GB. Eculizumab for dense deposit disease and C3 glomerulonephritis. Clin J Am Soc Nephrol 2012; 7: 748-56.

39. Oosterveld MJ, Garrelfs MR, Hoppe B, Florquin S, Roelofs JJ, van den Heuvel LP, Amann K, Davin JC, Bouts AH, Schriemer PJ, Groothoff JW. Eculizumab in Pediatric Dense Deposit Disease. Clin J Am SocNephrol 2015; 10: 1773-82.

40. Daina E, Noris M, Remuzzi G. Eculizumab in a patient with dense-deposit disease. $\mathrm{N}$ Engl J Med 2012; 366: 1161-3.

41. Inman M, Prater G, Fatima $H$, Wallace E. Eculizumab-induced reversal of dialysisdependent kidney failure from C3 glomerulonephritis. Clin Kidney J 2015; 8: 445-8.

42. Payette A, Patey N, Dragon-Durey MA, Frémeaux-Bacchi V, Le Deist F, Lapeyraque AL. A case of C3 glomerulonephritis successfully treated with eculizumab. Pediatr Nephrol 2015; 30: 1033-7.

43. Le Quintrec M, Lionet A, Kandel C, Bourdon F, Gnemmi V, Colombat 
M, Goujon

JM, Frémeaux-Bacchi

V, Fakhouri F. Eculizumab for treatment of rapidly progressive $\mathrm{C} 3$ glomerulopathy. Am J Kidney Dis 2015; 65: 484-9.

44. Zhang Y, Nester CM, Holanda DG, Marsh HC, Hammond RA, Thomas LJ, Meyer NC, Hunsicker LG, Sethi S, Smith RJ. Soluble CR1 Therapy Improves Complement Regulation in C3 Glomerulopathy. J Am Soc Nephrol 2013; 24: $1820-9$.

45. Nester CM, Smith RJ. Complement inhibition in c3 glomerulopathy. Semin Immunol 2016; 28: 241-9.

46. Zhang Y, Shao D, Ricklin D, Hilkin BM, Nester CM, Lambris JD, Smith RJ. Compstatin analog $\mathrm{Cp} 40$ inhibits complement dysregulation in vitro in $\mathrm{C} 3$ glomerulopathy. Immunobiology 2015; 220: 993-8.

47. D'souza Y, Short CD, McLeod D, Bonshek RE. Long-term follow-up of drusen-like lesions in patients with type II mesangiocapillary glomerulonephritis. $\mathrm{Br} \mathrm{J}$ Ophthalmol 2008; 92: 950-3.

48. Khandhadia S, Hakobyan S, Heng LZ, Gibson J, Adams DH, Alexander GJ, Gibson JM, Martin KR, Menon G, Nash K, Sivaprasad S, Ennis S, Cree AJ, Morgan BP, Lotery AJ. Age-related macular degeneration and modification of systemic complement factor $\mathrm{H}$ production through liver transplantation. Ophthalmology 2013; 120: 1612-8.

49. Leys A, Michielsen B, Leys M, Vanrenterghem Y, Missotten L, Van Damme B. Subretinal neovascular membranes associated with chronic membranoproliferative glomerulonephritis type II. Graefes Arch Clin Exp Ophthalmol 1990; 2284 99-504.

50. Farah SE, Fazelat A, Frei G. Treatment of subretinal neovascular membrane in a patient with membranoproliferative glomerulonephritis type II. Ophthalmic Surgery, Lasers, and Imaging Retina 2009; 40: 416-8.

51. Lu DF, Moon M, Lanning LD, McCarthy AM, Smith RJ. Clinical features and outcomes of 98 children and adults with dense deposit disease. Pediatr Nephrol 2012; 27: 773-81.
52. Zand L, Lorenz EC, Cosio FG, Fervenza FC, Nasr SH, Gandhi MJ, Smith RJ, Sethi S. Clinical findings, pathology, and outcomes of C3GN after kidney transplantation. J Am Soc Nephrol 2014; 25: 1110-7. 